\title{
PARTNERSTWO PUBLICZNO-PRYWATNE JAKO NOWOCZESNA FORMA REALIZACJI INWESTYCJI PUBLICZNYCH
}

\author{
Ewa Rygalik ${ }^{1}$ \\ Politechnika Częstochowska \\ Wydział Zarządzania
}

\begin{abstract}
Streszczenie: W obecnych czasach inwestycje posiadają kluczowe znaczenie w rozwoju gospodarczym danego państwa. Zarówno działanie jednostek samorządu terytorialnego, jak i przedsiębiorstw prywatnych przekłada się na wzrost gospodarczy. Aby jednostka samorządu terytorialnego mogła zrealizować zaplanowane inwestycje i przedsięwzięcia, musi posiadać wystarczające środki budżetowe, aczkolwiek coraz częściej instytucje państwowe odnotowują deficyt budżetowy, który uniemożliwia realizację kluczowych zadań. Jedną $\mathrm{z}$ form pozyskania finansowania rozwoju lokalnego jest współpraca w ramach partnerstwa publiczno-prywatnego (PPP). Partnerstwo publiczno-prywatne uważane jest za sposób finansowania przedsięwzięć publicznych przy możliwie najlepszym podziale zadań i ryzyk między stronami kontraktu. Celem artykułu jest zaprezentowanie partnerstwa publiczno-prywatnego jako nowoczesnej metody realizacji zadań publicznych przez jednostki samorządu terytorialnego (JST). Za metodę badawczą posłużyła analiza literatury oraz wnioskowanie dedukcyjne. Ponadto zaprezentowano przykład realizacji inwestycji w ramach partnerstwa publiczno-prywatnego. Opracowanie umożliwiło wyciągnięcie wniosku, iż PPP jest niezmiernie ważne i stanowi dla jednostek gminnych szansę na terminowe wywiązywanie się z podjętych działań inwestycyjnych.
\end{abstract}

Słowa kluczowe: inwestycje, jednostki samorządu terytorialnego, partnerstwo publiczno-prywatne, współpraca

DOI: $10.17512 /$ znpcz.2020.3.03

\section{Wprowadzenie}

Istotną rolą jednostek samorządu terytorialnego (JST) jest zapewnienie mieszkańcom dostępności do usług posiadających charakter użyteczności publicznej oraz nieustanne stymulowanie rozwoju społeczno-gospodarczego. Najważniejsze znaczenie w tym zakresie odgrywają jednostki gminne, które odpowiedzialne są za realizację inwestycji na poziomie lokalnym. Do realizacji zamierzonych zadań niezbędne są środki budżetowe, które samorządy coraz częściej pozyskują w ramach partnerstwa publiczno-prywatnego. Ścisła współpraca wynikająca z partnerstwa publiczno-prywatnego przekłada się na obopólne korzyści i zmniejszenie ryzyka niepowodzenia zaplanowanej inwestycji. Podjęty w artykule temat dotyczy

\footnotetext{
${ }^{1}$ Ewa Rygalik, mgr, ewasikora19@gmail.com, ORCID: 0000-0002-0903-806X
} 
realizacji przedsięwzięć inwestycyjnych zarówno przez sektor publiczny, jak i prywatny. PPP zwiększa skuteczność i ułatwia realizację podjętych inwestycji oraz zmniejsza gminny deficyt budżetowy. Wynika z tego, iż PPP jest nowoczesną formą realizacji zadań publicznych (inną od dotychczas stosowanych).

Inwestycje uważane są za jeden z nieodłącznych elementów stymulujących polską gospodarkę. Z kolei realizacja przedsięwzięć inwestycyjnych przez gminy ściśle połączona jest ze wzrostem konkurencyjności oraz zaspokajaniem potrzeb społeczności lokalnej. Rosnący deficyt budżetowy gmin wymusza na JST szukanie alternatywnych sposobów finansowania zaplanowanych zadań. Partnerstwo publiczno-prywatne należy do tych form inwestycji publicznych, gdzie wszystkie podmioty angażujące się w przedsięwzięcie powinny osiągnąć szereg zamierzonych korzyści. Ponadto realizacja zadań publicznych musi przynieść zadowolenie finalnemu odbiorcy inwestycji społeczności lokalnej. Partnerstwo publiczno-prywatne umożliwia pokonanie obecnych ograniczeń podczas realizacji inwestycji publicznych.

Celem artykułu jest zaprezentowanie partnerstwa publiczno-prywatnego jako nowoczesnej metody realizacji zadań publicznych przez jednostki samorządu terytorialnego (JST). Za metodę badawczą posłużyła analiza literatury oraz wnioskowanie dedukcyjne. Ponadto zaprezentowano przykład realizacji inwestycji w ramach partnerstwa publiczno-prywatnego. Opis przypadku (case study) uważany jest za metodę badawczą służącą zobrazowaniu pewnego zjawiska bądź konkretnej sytuacji. W tym przypadku analizie poddano realizację inwestycji w Gminie Miasto Płock. Inwestycja ta zakończyła się sukcesem i należy do udanych przedsięwzięć realizowanych za pomocą PPP. Opracowanie umożliwiło wyciągnięcie wniosku, iż partnerstwo publiczno-prywatne jest niezmiernie ważne i stanowi szansę dla jednostek gminnych na terminowe wywiązywanie się z podjętych działań inwestycyjnych.

\section{Inwestycje w jednostkach samorządu terytorialnego}

Inwestycje uważane są za nieodłączny element rozwoju danej jednostki gospodarczej (Nowicka 2012, s. 25-28). Umożliwiają one rozwój oraz osiągnięcie wysokiej pozycji konkurencyjnej przedsiębiorstwa. Realizacja projektów inwestycyjnych występuje zarówno w sektorze prywatnym, jak i wśród jednostek publicznych. Inwestycje podejmowane przez JST można zdefiniować jako inwestycje posiadające charakter infrastrukturalny, ściśle połączone z zadaniami własnymi jednostki, kreujące wartość dodaną oraz podnoszące konkurencyjność poprzez rozwój i wzrost danej instytucji (Kik, Marona, Nalepka 2016, s. 37).

Jednostki samorządu terytorialnego zobligowane są do realizacji szeregu zadań publicznych. Najważniejsze zadania lokalne leżą po stronie samorządu gminnego, który bezpośrednio działa w interesie obywateli (Adamowicz, Skarżyńska 2017, s. 319). Gmina jest podstawową jednostką samorządu terytorialnego, realizującą szereg zadań własnych w interesie i dla dobra społeczności lokalnej (Szczachowicz 2015, s. 256-258). Cechami charakterystycznymi zadań własnych są:

- lokalny charakter,

- zaspokojenie potrzeb obywateli,

- finansowanie przez JST. 
Zadania, do których zobowiązane są jednostki samorządu terytorialnego, można podzielić na zadania własne, powierzone, zlecone bądź na zadania fakultatywne i obligatoryjne. Jednostki należące do sektora publicznego posiadają znaczną swobodę co do wykonywania powierzonych im zadań. Swoboda ta dotyczy realizacji działań oraz wydatkowania posiadanych środków finansowych. Finansowanie zadań własnych pochodzi z dochodów osiąganych przez jednostkę gminną (m.in. podatki i opłaty) oraz z subwencji i dotacji. Do zadań własnych jednostek samorządu terytorialnego należą sprawy związane z (Gołąbiewski 2017, s. 20-25):

- drogami, ulicami, mostami;

- ładem przestrzennym, ochroną środowiska, gospodarką nieruchomościami;

- lokalnym transportem;

- ochroną zdrowia, edukacją publiczną, bezpieczeństwem obywateli;

- utrzymaniem w najlepszym stanie gminnych obiektów użyteczności administracyjnej oraz publicznej.

Każda gmina tworzy indywidualną oraz niepowtarzalną wspólnotę składającą się z określonego terytorium oraz mieszkańców. W związku z tym jednostki gminne posiadają indywidualne podejście do zakresu oraz realizacji poszczególnych zadań (Jeremko, Cierpiszewski 2013, s. 77).

Inwestycje publiczne coraz częściej realizowane są poza strukturami administracji publicznej. Jednostki samorządu terytorialnego podejmują decyzję dotyczącą prywatyzacji zadań publicznych, angażując $\mathrm{w}$ realizację danego przedsięwzięcia przedsiębiorstwa prywatne. W obecnych czasach ważniejszymi wykonawcami ciągle narastających inwestycji na rzecz dobra społecznego stają się podmioty niepubliczne (Dolnicki 2012). Tym samym JST coraz częściej zawierają współpracę z sektorem prywatnym w ramach partnerstwa publiczno-prywatnego. Partnerstwo publiczno-prywatne okazuje się szansą na terminową realizację inwestycji bez angażowania środków publicznych (Filipiak 2016, s. 178-181).

\section{Idea partnerstwa publiczno-prywatnego}

Partnerstwo publiczno-prywatne można zaliczyć do nowoczesnych metod realizacji zadań publicznych. Jednoczesne wykorzystywanie potencjału sektora prywatnego i publicznego przekłada się na efektywne oraz w pełni skuteczne świadczenie usług publicznych. Jest to alternatywne i zupełnie inne od dotychczas stosowanych źródło finansowania zadań jednostek samorządu terytorialnego. Instytucje publiczne decydujące się na realizację danej inwestycji w ramach PPP stają się nabywcami usług, a więc całkowicie zmieniają swoją rolę. Partnerstwo publiczno-prywatne może być wykorzystywane podczas modernizacji budynków publicznych, budowania i utrzymywania dróg, mostów czy infrastruktury turystycznej. Wynika $\mathrm{z}$ tego, iż ta nowoczesna forma realizacji inwestycji publicznych może dotyczyć budowy od podstaw bądź remontu i ulepszenia funkcjonujących już składników majątkowych (Solheim-Kile, Wald 2019).

Partnerstwo publiczno-prywatne obejmuje współpracę pomiędzy jednostką publiczną a partnerem prywatnym w celu realizacji zamierzonych zadań publicznych (Osei-Kyei, Chan 2018, s. 132-133). Strony kontraktu współpracują w oparciu o wzajemne zaufanie, dzieląc się ryzykiem, zyskiem oraz odpowiedzialnością za realizację 
poszczególnych etapów projektu. Ponadto cechą charakterystyczną partnerstwa publiczno-prywatnego jest długoterminowa forma współpracy (od kilku do kilkunastu lat). W PPP przedsiębiorstwo prywatne najczęściej ponosi całość bądź część nakładów niezbędnych do realizacji zamierzonego przedsięwzięcia. Do głównych zalet tej formy finansowania zalicza się m.in. wzrost efektywności danej inwestycji, odciążenie budżetu publicznego oraz wykorzystywanie najnowszej technologii (Osei-Kyei, Chan 2017).

Podjęcie inicjatywy w ramach partnerstwa publiczno-prywatnego umożliwia osiągnięcie wielu korzyści dla obu stron kontraktu. Do korzyści wynikających ze współpracy PPP zalicza się:

- obniżenie kosztów inwestycyjnych;

- zastosowanie najnowszych technologii na poszczególnych etapach projektu;

- zmniejszenie zadłużenia JST;

- promocję jednostek prywatnych;

- otrzymywanie przez stronę prywatną wynagrodzenia przez cały okres trwania umowy inwestycyjnej.

Pomimo osiąganych korzyści nie należy zapominać, iż inwestycje realizowane w ramach PPP niosą za sobą wiele ryzyk. Istotne znaczenie posiada ryzyko prawne, regulacyjne oraz makroekonomiczne. Jednostki publiczne szczególnie narażone są na całkowitą utratę kontroli nad realizowanym przedsięwzięciem oraz błędne oszacowanie kosztów inwestycji. W partnerstwie publiczno-prywatnym występuje zjawisko tzw. alokacji ryzyka. Zjawisko to dotyczy przenoszenia ryzyka na podmiot, który będzie potrafił w lepszy sposób nim zarządzać (Osei-Kyei i in. 2017, s. 88-91). Każde działanie, również to podejmowane w ramach partnerstwa publiczno-prywatnego, wiąże się z ryzykiem. Ryzyka nie da się w żaden sposób wyeliminować, ponieważ uważane jest za zjawisko powszechne. Wszędzie tam, gdzie występują działania inwestycyjne, można zaobserwować ryzyko. W partnerstwie publiczno-prywatnym duże znaczenie posiada odpowiedni podział ryzyka między strony kontraktu. Dane ryzyko powinna ponosić ta strona, która w najlepszy sposób będzie nim zarządzać i sobie z nim poradzi (Chluska, Sikora 2018). Dzięki temu można ograniczyć negatywne skutki ryzyka rzutujące na realizację każdego etapu przedsięwzięcia realizowanego w ramach PPP. Uważa się, iż gwarancją odniesienia sukcesu w projektach inwestycyjnych jest prawidłowe i rzetelne zarządzanie ryzykiem.

Partnerstwo publiczno-prywatne jest szansą dla jednostek gminnych na realizację zadań statusowych pomimo znacznego deficytu budżetowego. Inicjatywa podjęcia współpracy w ramach PPP zawsze leży po stronie sektora publicznego, gdyż to JST musi podjąć ostateczną decyzję, jaka forma działań będzie najbardziej korzystna $\mathrm{w}$ danym projekcie inwestycyjnym.

\section{Case study - realizacja przedsięwzięć inwestycyjnych w ramach partnerstwa publiczno-prywatnego}

W obecnych czasach jednostki samorządu terytorialnego szukają innowacyjnych metod realizacji planowanych zadań publicznych. Zadania te coraz częściej dotyczą zwiększenia efektywności energetycznej budynków publicznych oraz wpasowują się 
w idee ochrony środowiska. Na realizację przedsięwzięcia w ramach partnerstwa publiczno-prywatnego w tym zakresie w 2014 roku zdecydowała się Gmina Miasto Płock. Inwestycja ta dotyczyła „Modernizacji energetycznej obiektów użyteczności publicznej w Płocku". Inwestycja przewidywała zwiększenie efektywności energetycznej w sześciu budynkach użyteczności publicznej zlokalizowanych w mieście Płocku. Byłyby to trzy przedszkola, dwa zespoły szkół oraz jeden ośrodek szkolno-wychowawczy.

Cele szczegółowe projektu dotyczyły:

- poprawy warunków użytkowania szkół publicznych;

- wykorzystania odnawialnych źródeł energii;

- zmniejszenia kosztów eksploatacji modernizowanych obiektów;

- obniżenia emisji gazów cieplarnianych (znaczna poprawa jakości powietrza w mieście Płocku);

- mniejszego zużycia energii w placówkach oświatowych (http://www.plock.eu/...).

Podmiotem reprezentującym stronę publiczną został Urząd Miasta Płock, z kolei partnerami prywatnymi okazały się Siemens Finance oraz Siemens Sp. z o.o. Umowa między stronami kontraktu została podpisana 4 listopada 2015 r. na okres 17 lat. Łączna wartość nakładów inwestycyjnych wyniosła 18168 776,08 zł (projekt został sklasyfikowany jako niewielkie przedsięwzięcia). Wszystkie niezbędne nakłady inwestycyjne w $100 \%$ zostały pokryte przez partnera prywatnego. Spółka Siemens będzie przez cały okres trwania umowy otrzymywać wynagrodzenie ze środków zaoszczędzonych na energii cieplnej oraz elektrycznej (konsorcjum Siemens Sp. z o.o. zobligowane jest do osiągnięcia zagwarantowanych w umowie oszczędności energetycznych). Model wynagrodzenia został określny jako płatność za dostępność modernizowanych obiektów. Wynagrodzenie spółki Siemens wypłacane będzie w cyklicznych płatnościach, jednak będą one poprzedzone wcześniejszą weryfikacją, czy faktycznie zostały osiągnięte zakładane poziomy oszczędności energii cieplnej oraz elektrycznej. Jeśli planowana oszczędność nie została zrealizowana, wynagrodzenie partnera prywatnego zostaje odpowiednio pomniejszone. W omawianym projekcie wyłącznie partner prywatny odpowiedzialny jest za etap robót budowlanych oraz zarządzanie inwestycją publiczną. Zarówno sektor publiczny, jak i sektor prywatny odpowiedzialny jest za szereg ryzyk. Podmiot publiczny odpowiedzialny jest m.in. za ryzyka:

- dokumentacji technicznej;

- zmiany w prawie, w tym zmiany stawek podatków oraz energii elektrycznej i cieplnej:

- zapłaty określonego w umowie wynagrodzenia na rzecz konsorcjum Siemens Sp. z o.o.;

- nieuzgodnienia $\mathrm{z}$ inwestorem prywatnym integracji w system zarządzania energią;

- zmiany sposobu wykorzystywania modernizowanych obiektów. Z kolei partner prywatny ponosi ryzyka związane z:

- całkowitym finansowaniem inwestycji oraz jego ewentualną utratą;

- opracowaniem w sposób kompleksowy dokumentacji projektowej;

- niedoszacowaniem przedmiotu umowy partnerstwa publiczno-prywatnego;

- opóźnieniem zakończenia prac inwestycyjnych; 
- niezgodnością wykonania podjętych prac termomodernizacyjnych;

- wzrostem kosztów utrzymania modernizowanych obiektów bądź obsługi całego systemu zarządzania energią (https://www.ppp.gov.p1/...).

Omawiana inwestycja przyczyniła się do mniejszej emisji zanieczyszczeń oraz podniesienia jakości świadczonych usług publicznych przez samorząd gminny. Ponadto Gmina Płock nie powiększyła posiadanego deficytu budżetowego, a tym samym mogła realizować inne zaplanowane zadania umożliwiające zaspokojenie potrzeb społeczności lokalnej.

Realizacja każdego przedsięwzięcia inwestycyjnego wymaga dużego zaplecza finansowego, niezależnie od tego, czy przedsięwzięcie wykonuje jednostka prywatna, czy instytucja publiczna. Dążąc do zwiększenia efektywności wykonywanych inwestycji, jednostki samorządu terytorialnego nawiązują współpracę z przedsiębiorstwami prywatnymi. W obecnych czasach coraz bardziej popularna staje się taka forma współpracy. Aby dane przedsięwzięcie zaliczyć do udanych inwestycji, etapy PPP muszą być poddawane ciągłej kontroli i ocenie, czy przebiegają według wcześniej określonego planu.

Podczas realizacji przedsięwzięć inwestycyjnych należy ciągle monitorować oraz wprowadzać nowe metody rozwiązań. Konieczne jest także planowanie, kierowanie i kontrola poszczególnych etapów danego projektu. Zaprezentowany przykład realizowany za pomocą partnerstwa publiczno-prywatnego pozwala wyciągnąć kilka ogólnych wniosków:

- PPP umożliwia podnoszenie efektywności usług publicznych, a tym samym wykorzystanie w inwestycjach publicznych doświadczenia sektora prywatnego.

- Każda decyzja inwestycyjna wymaga zapewnienia ciągłego dostępu do źródeł finansowania.

- Wdrożenie oraz wykorzystanie partnerstwa publiczno-prywatnego uważane jest za trudny i skomplikowany proces (najczęściej wynika to z odmiennych celów strategicznych stron kontraktu).

- Jedną z głównych korzyści wynikających z PPP jest skrócenie czasu realizacji inwestycji publicznej oraz przeznaczenie zaoszczędzonych środków publicznych na realizację innych zadań, osiągając zamierzone cele strategiczne (Turek, Jonek-Kowalska 2011, s. 48).

\section{Podsumowanie}

W wielu krajach jednostki samorządu terytorialnego są kluczowym inwestorem publicznym. Szacuje się, że w Polsce ponad 50\% wszystkich wydatków publicznych stanowią wydatki inwestycyjne (Wyszkowska, Wyszkowski 2016, s. 57). Jednakże realizacja zadań publicznych coraz częściej przenoszona jest poza struktury jednostek samorządu terytorialnego (Małecka-Łyszczek 2013, s. 68). Wykorzystywanie partnerstwa publiczno-prywatnego okazuje się doskonałym instrumentem podczas realizacji różnego rodzaju zadań publicznych. Inwestycje prowadzone w ramach partnerstwa publiczno-prywatnego charakteryzują się wysoką jakością i krótkim okresem wykonania. Dzięki PPP jednostki należące do sektora publicznego podnoszą swoją efektywność w kontekście realizacji statutowych zadań publicznych. 
Partnerstwo publiczno-prywatne jest szansą na realizację wszystkich inwestycji publicznych. Podejmując decyzję o realizacji przedsięwzięcia w ramach PPP, należy wykonać wiele złożonych analiz. Konieczne jest zdefiniowanie celu, określenie każdego etapu działania oraz ciągła kontrola. Efektem finalnym prawidłowo przeprowadzonego partnerstwa publiczno-prywatnego jest wzrost zadowolenia społecznego oraz rozwój gospodarczy. PPP umożliwia realizację inwestycji, które z powodu braku środków w jednostkach samorządu terytorialnego najprawdopodobniej w najbliższej przyszłości nie byłyby zrealizowane.

Analiza realizowanej inwestycji w Gminie Płock pozwoliła wyciągnąć wniosek, iż partnerstwo publiczno-prywatne jest złożonym procesem, który musi być przemyślany i poddawany ciągłej kontroli. PPP jest szansą osiągnięcia wielu korzyści przez strony kontraktu, ale również przynosi wiele zagrożeń i nowych ryzyk, z którymi partnerzy muszą sobie poradzić. Opis przypadku w dalszych etapach rozważań zostanie rozszerzony o badania ilościowe, które umożliwią zaprezentowanie osiągniętych korzyści, nie tylko dla JST czy przedsiębiorstwa prywatnego, ale także dla społeczności lokalnej.

\section{Literatura}

1. Adamowicz M., Skarżyńska P. (2017), Rola samorządu lokalnego w realizacji zadań oświatowych na przyktadzie samorząu gminy Szelków, „Annales Universitiatis Mariae Curie-Skłodowska", Vol. 24(2).

2. Chluska J., Sikora E. (2018), Partnerstwo publiczno-prywatne - szanse czy ryzyko?, „Studia Ekonomiczne. Zeszyty Naukowe Uniwersytetu Ekonomicznego w Katowicach”, nr 369.

3. Dolnicki B. (2012), Samorzad terytorialny, Wolters Kluwer, Warszawa.

4. Filipiak B.Z. (2016), Changes in the Direction of Financing Tasks of Local Government Units, „Zeszyty Naukowe Wyższej Szkoły Bankowej w Poznaniu”, t. 70, nr 5.

5. Gołąbiewski M. (2017), Performance of Public Tasks by Companies of Local Government Units, „Central European Review of Economics \& Finance”, Vol. 19, No. 3.

6. http://www.plock.eu/pl/modernizacja_energetyczna_obiektow_uzytecznosci_publicznej _. w_plocku.html (dostęp: 20.06.2020).

7. https://www.ppp.gov.pl/modernizacja-energetyczna-obiektow-uzytecznosci-publicznejw-plocku-/ (dostęp: 20.06.2020).

8. Jeremko M., Cierpiszewski O. (2013), Definiowanie zadań w gminach na przykładzie Urzędu Gminy Tarnowo Podgórne, ,Zeszyty Naukowe Uniwersytetu Szczecińskiego. Finanse, Rynki Finansowe, Ubezpieczenia”, nr 64/2.

9. Kik I., Marona B., Nalepka A. (2016), Wykorzystanie środków zwrotnych na realizację inwestycji gmin w województwie małopolskim, „Zeszyty Naukowe Uniwersytetu Ekonomicznego w Krakowie", nr 8(956).

10. Małecka-Łyszczek M. (2013), Pojęcie i podziały zadań publicznych ze szczególnym uwzględnieniem zadań samorzadu terytorialnego, „Zeszyty Naukowe Uniwersytetu Ekonomicznego w Krakowie. Problemy Społeczne, Polityczne i Prawne”, nr 921.

11. Nowicka J. (2012), Społeczne oddziaływanie inwestycji prywatnych i publicznych w Polsce, „Rynek - Społeczeństwo - Kultura”, nr 1.

12. Osei-Kyei R., P.C. Chan A. (2017), Developing a Project Success Index for Public-Private Partnership Projects in Developing Countries, „Journal of Infrastructure Systems”, Vol. 23(4).

13. Osei-Kyei R., P.C. Chan A. (2018), Stakeholders Perspectives on the Successcriteria for Public-Private Partnership Projects, „International Journal of Strategic Property Management”, Vol. 22(2). 
14. Osei-Kyei R., P.C. Chan A., Javed A.A., Ameyaw E.E. (2017), Critical Success Criteria for Public-Private Partnership Projects: International Experts' Opinion, „Vilnius Gediminas Technical University", Vol. 21(1).

15. Solheim-Kile E., Wald A. (2019), Extending the Transactional View on Public-Private Partnership Projects: Role of Relational and Motivational Aspects in Goal Alignment, „Journal of Construction Engineering and Management”, Vol. 145(5).

16. Szczachowicz H. (2015), Wykonywanie zadań publicznych w jednostkach samorządu terytorialnego, ,Zeszyty Naukowe Zbliżenia Cywilizacyjne”, t. 11.

17. Turek M., Jonek-Kowalska I. (2011), Partnerstwo publiczno-prywatne jako metoda finansowania zadań jednostek samorzadu terytorialnego $w$ Polsce. Identyfikacja szans i zagrożeń, „Zeszyty Naukowe Politechniki Śląskiej. Organizacja i Zarządzanie”, z. 58, nr kol. 1858.

18. Wyszkowska D., Wyszkowski A. (2016), Samorzad terytorialny jako inwestor publiczny w Polsce na tle innych krajów OECD, „Wiadomości Statystyczne”, nr 12(667).

\title{
A PUBLIC-PRIVATE PARTNERSHIP AS A MODERN FORM OF IMPLEMENTING PUBLIC INVESTMENTS
}

\begin{abstract}
Nowadays, investments are of key importance in the economic development of a given country. Both the activity of local government units and private enterprises translates into economic growth. However, ensuring the basic needs of the local community lies with communal units. For a local government unit to be able to implement planned investments and projects, it must have sufficient budgetary resources. However, more and more often state institutions record a budget deficit that prevents the implementation of key tasks. One of the forms of obtaining financing for local development is cooperation under a public-private partnership (PPP). A public-private partnership is considered a way of financing public enterprises with the best possible division of tasks and risks between the parties to the contract. The purpose of the article is to present public-private partnerships as a modern method of implementing public tasks by local government units. Literature analysis and deductive reasoning served as the research method. In addition, an example of the implementation of investments under public-private partnerships was presented. The study made it possible to conclude that PPP is extremely important and provides an opportunity for municipal units to meet their investment activities in a timely manner.
\end{abstract}

Keywords: investments, local government units, public-private partnership, cooperation 